\title{
Longidorus profundorum Hooper, 1965 (Nematoda: Dorylaimida) in the Slovak Republic
}

\author{
M. LIŠKOVÁ \\ Institute of Parasitology, Slovak Academy of Sciences, Hlinkova 3, 04001 Košice, Slovak Republic, \\ E-mail:marta_liskova@yahoo.com
}

\begin{abstract}
Summary
The species Longidorus profundorum Hooper, 1965 was for the first time recorded in the territory of Slovakia. It was observed in the rhizosphere of Fraxineto-Quercetum forest of riverine plain along Moravia River in south-western part of country, close to boundary with Austria. Morphometrics of females, males and four juvenile stages, morfological and molecular characteristic of Slovakian specimens are presented.
\end{abstract}

Keywords: Nematoda; Longidoridae; Longidorus profundorum; morphology; molecular characteristic; ecology; flooded forest; Slovak Republic

\section{Introduction}

Longidorus profundorum was for the first time recorded in England, in the rhizosphere of apple and quince stocks, grasses and bushes (Hooper, 1965). The species is occurring in numerous countries of Europe, e. g. in Switzerland (Klingler et al., 1983; Lamberti et al., 2001), Spain (Andres \& Bello, 1984) Belgium, Bulgaria, France, Germany, Great Britain, Northern Ireland and France (Topham \& Alphey, 1985; Brown \& Taylor, 1987), and Russia (Prikhodko, 1988; Romanenko, 1994). During investigation of longidorid nematodes in floodplain forests in Slovakia a total of five species were identified - Longidorus elongatus, L. euonymus, L. intermedius, L. poessneckensis and $X$. diversicaudatum (Lišková \& Sturhan, 2000). Most frequent were L. intermedius, L. poessneckensis (very often in mixture of these two species) and $X$. diversicaudatum, species which can be considered as indicators for flooded forest. Additional study of the longidorids in floodplain forests along Moravia River provides information about occurrence of the species Longidorus profundorum, a new species for the territory of Slovakia.
The morphometrical and molecular characteristic and ecology of the Slovak specimens of L. profundorum are presented here.

\section{Material and methods}

Locality and habitat

In Slovakia the species Longidorus profundorum was recorded in the south-western part of the country, orographic unit Borská, or Záhorská nížina plain, near village Gajary, $48^{\circ} 28^{\prime} \mathrm{N} 16^{\circ} 56^{\prime} \mathrm{E}$, in soil of regular waterlogging soils along Moravia River with Fraxineto-Quercetum forest type with undergrowth of Rubus caesius, Carex and $G a-$ lium spp. The sampling site is situated at an altitude of about $150 \mathrm{~m}$, it is characteristic by warm climate with an isotherm of $9.5^{\circ} \mathrm{C}$, isohyet of about $600 \mathrm{~mm}$ and clayloamy soil with lower admixture of sand and gravel, $\mathrm{pH}$ 5.0, soil type Fluvisol derived from river sediments.

\section{Nematological studies}

In October 2008 soil samples were collected from the rhizosphere of forest trees with undergrowth. The nematodes were extracted from soil using a sieving and decanting technique (Brown \& Boag, 1988). They were fixed by $4 \%$ hot formol and mounted in anhydrous glycerin on permanent slides for examination.

\section{Molecular study}

Total genomic DNA was extracted from two single individuals with a rapid technique (Stanton et al., 1998). In brief, the tubes containing individual nematodes in $20 \mu \mathrm{l}$ of $0.25 \mathrm{M} \mathrm{NaOH}$ were incubated overnight at room temperature, thereafter heated to $99{ }^{\circ} \mathrm{C}$ for $3 \mathrm{~min}$. Afterwards $10 \mu \mathrm{l}$ of $0.25 \mathrm{M} \mathrm{HCl}$, and $5 \mu \mathrm{l}$ each of $0.5 \mathrm{M}$ Tris- $\mathrm{HCl}(\mathrm{pH} 8)$ and $2 \%$ Triton X-100 were added and the mixture was 
incubated again for $3 \mathrm{~min}$ at $99^{\circ} \mathrm{C}$. Finally, the DNA suspension was cooled and the DNA was used directly for PCR. 18S gene of ribosomal DNA was amplified in two overlapping fragments and primer combination was $988 \mathrm{~F}+1912 \mathrm{R}$ for the first fragment and $1813 \mathrm{~F}+2646 \mathrm{R}$ for the second fragment (Holterman et al., 2006). D2/D3 expansion segments of $28 \mathrm{~S}$ gene were amplified using D2A and D3B primers (De Ley et al., 2005). PCR reactions were performed in a $25 \mu \mathrm{l}$ volume with the following master mix: one PCR bead (GE Healthcare, Buckinghamshire, UK), $20 \mu \mathrm{l}$ double distilled sterile water, $2.0 \mu \mathrm{l}$ each primer $(10 \mathrm{pmol} / \mu \mathrm{l})$ and to this $1.0 \mu \mathrm{l}$ of DNA was added as a template for PCR. The cycling conditions were: first denaturation for $3 \mathrm{~min}$ at $94{ }^{\circ} \mathrm{C}, 40$ cycles with $30 \mathrm{~s}$ at $94{ }^{\circ} \mathrm{C}, 30 \mathrm{~s}$ at $55^{\circ} \mathrm{C}, 30 \mathrm{~s}$ at $72{ }^{\circ} \mathrm{C}$ and a final elongation step was run at $72{ }^{\circ} \mathrm{C}$ for $10 \mathrm{~min}$. PCR reaction was separated on $1.5 \%$ agarose gel in Tris-Acetate-EDTA (TAE), stained with syber-safe and visualized with UV illumination $(312 \mathrm{~nm})$. Amplicons were separated on agarose gels and recovered from the gel by excision and purified with a QIAGEN gel extraction kit (Qiagen, Hilden, Germany) and directly sequenced in both directions (Macrogen, Korea). Sequencher ${ }^{\mathrm{TM}} 4.8$ (Genes Codes. Corp., Ann Arbor, MI, USA) software was used to assemble and view sequences and check for base-calling errors.

Table 1. Morphometrics of Longidorus profundorum from the Slovak Republic (measurements given in $\mu \mathrm{m}$, except for body length)

\begin{tabular}{|c|c|c|c|c|c|c|}
\hline Locality & & & & Gajary & & \\
\hline Type of vegetation & & & Fraxinet & o-Quercetum & & \\
\hline Stage & $\mathrm{J}_{1}$ & $\mathrm{~J}_{2}$ & $\mathrm{~J}_{3}$ & $\mathrm{~J}_{4}$ & Females & Males \\
\hline $\mathrm{n}$ & 4 & 4 & 6 & 10 & 8 & 3 \\
\hline $\mathrm{L}(\mathrm{mm})$ & $\begin{array}{c}1.42 \pm 0.1 \\
(1.31-1.57)\end{array}$ & $\begin{array}{c}2.35 \pm 0.1 \\
(2.14-2.45)\end{array}$ & $\begin{array}{c}3.68 \pm 0.3 \\
(3.26-3.96)\end{array}$ & $\begin{array}{c}5.09 \pm 0.5 \\
(4.01-6.09)\end{array}$ & $\begin{array}{c}6.87 \pm 1.9 \\
(6.48-7.77)\end{array}$ & $\begin{array}{c}6.26 \pm 2.9 \\
(5.92-6.46)\end{array}$ \\
\hline $\mathrm{a}$ & $\begin{array}{c}63.7 \pm 5.9 \\
(56.6-72.5)\end{array}$ & $\begin{array}{c}66.2 \pm 7.6 \\
(59.7-76.0)\end{array}$ & $\begin{array}{c}75.0 \pm 4.3 \\
(70.9-85.8)\end{array}$ & $\begin{array}{c}90.8 \pm 8.1 \\
(75.1-103.3)\end{array}$ & $\begin{array}{c}103.8 \pm 10.1 \\
(90.0-122.0)\end{array}$ & $\begin{array}{c}99.9 \pm 4.3 \\
(95.6-104.1)\end{array}$ \\
\hline $\mathrm{b}$ & $\begin{array}{c}4.8 \pm 0.3 \\
(4.4-5.2)\end{array}$ & $\begin{array}{c}6.9 \pm 0.4 \\
(6.6-7.4)\end{array}$ & $\begin{array}{c}9.6 \pm 0.9 \\
(8.5-11.0)\end{array}$ & $\begin{array}{c}13.8 \pm 2.7 \\
(10.0-19.0)\end{array}$ & $\begin{array}{c}14.3 \pm 1.1 \\
(12.9-16.1)\end{array}$ & $\begin{array}{c}14.3 \pm 1.5 \\
(12.8-15.8)\end{array}$ \\
\hline $\mathrm{c}$ & $\begin{array}{c}34.4 \pm 2.8 \\
(31.0-37.8)\end{array}$ & $\begin{array}{c}57.5 \pm 4.1 \\
(53.6-61.3)\end{array}$ & $\begin{array}{c}82.9 \pm 6 \\
(75.4-90.1)\end{array}$ & $\begin{array}{c}112.3 \pm 10.8 \\
(91.6-126.9)\end{array}$ & $\begin{array}{c}152.7 \pm 15.6 \\
(135.0-183.3)\end{array}$ & $\begin{array}{c}143.9 \pm 11.2 \\
(134.5-156.3)\end{array}$ \\
\hline$c^{\prime}$ & $\begin{array}{c}2.6 \pm 0.2 \\
(2.3-2.8)\end{array}$ & $\begin{array}{c}1.5 \pm 0.2 \\
(1.3-1.7)\end{array}$ & $\begin{array}{c}1.2 \pm 0.04 \\
(1.1-1.22)\end{array}$ & $\begin{array}{c}1.0 \pm 0.08 \\
(0.92-1.14)\end{array}$ & $\begin{array}{c}0.9 \pm 0.1 \\
(0.8-1.0)\end{array}$ & $\begin{array}{l}0.9 \pm 0.05 \\
(0.8-0.9)\end{array}$ \\
\hline $\mathrm{V}(\%)$ & - & - & - & - & $\begin{array}{c}52.1 \pm 1.5 \\
(50.5-55.2)\end{array}$ & - \\
\hline Odontostyle & $\begin{array}{c}53.5 \pm 1.7 \\
(52.0-56.0)\end{array}$ & $\begin{array}{c}59.5 \pm 2.5 \\
(56.0-62.0)\end{array}$ & $\begin{array}{c}70.6 \pm 7.9 \\
(60.0-80.0)\end{array}$ & $\begin{array}{c}84.5 \pm 3.5 \\
(80.0-90.0)\end{array}$ & $\begin{array}{c}101.3 \pm 5.8 \\
(96.0-114.0)\end{array}$ & $\begin{array}{c}92.3 \pm 6.4 \\
(85.0-96.0)\end{array}$ \\
\hline Odontophore & $\begin{array}{c}40.7 \pm 0.9 \\
(40.0-42.0)\end{array}$ & $\begin{array}{c}48.5 \pm 1.0 \\
(48.0-50.0)\end{array}$ & $\begin{array}{c}48.2 \pm 8.9 \\
(40.0-60.0)\end{array}$ & $\begin{array}{c}58.9 \pm 5.8 \\
(48.0-68.0)\end{array}$ & $\begin{array}{c}64.8 \pm 4.3 \\
(60.0-68.0)\end{array}$ & $\begin{array}{c}70.0 \pm 2.0 \\
(68.0-72.0)\end{array}$ \\
\hline Replacement odontostyle & $\begin{array}{c}59.4 \pm 0.8 \\
(58.0-60.0)\end{array}$ & $\begin{array}{c}74.0 \pm 4.0 \\
(68.0-76.0)\end{array}$ & $\begin{array}{c}85.0 \pm 2.7 \\
(82.0-88.0)\end{array}$ & $\begin{array}{c}94.6 \pm 5.9 \\
(85.0-102.0)\end{array}$ & - & - \\
\hline Oral aperture to guiding ring & $\begin{array}{c}20.1 \pm 0.6 \\
(19.6-21.0)\end{array}$ & $\begin{array}{c}22.7 \pm 2.2 \\
(22.0-24.8)\end{array}$ & $\begin{array}{c}26.8 \pm 1.9 \\
(24.0-28.8)\end{array}$ & $\begin{array}{c}31.1 \pm 1.8 \\
(28.0-34.0)\end{array}$ & $\begin{array}{c}36.0 \pm 0.0 \\
(36.0-36.0)\end{array}$ & $\begin{array}{c}37.1 \pm 1.6 \\
(35.2-38.0)\end{array}$ \\
\hline Length of tail & $\begin{array}{c}42.0 \pm 4.9 \\
(36.0-48.0)\end{array}$ & $\begin{array}{c}41.0 \pm 2.0 \\
(40.0-44.0)\end{array}$ & $\begin{array}{c}44.5 \pm 2.9 \\
(40.0-49.0)\end{array}$ & $\begin{array}{c}45.1 \pm 3.9 \\
(36.0-48.8)\end{array}$ & $\begin{array}{c}45.1 \pm 4.3 \\
(36.0-48.0)\end{array}$ & $\begin{array}{c}43.7 \pm 3.8 \\
(41.0-48.0)\end{array}$ \\
\hline Length of J (hyaline portion of tail) & $\begin{array}{c}9.5 \pm 0.9 \\
(8.0-10.0)\end{array}$ & $\begin{array}{c}7.0 \pm 0.8 \\
(6.0-8.0)\end{array}$ & $\begin{array}{c}7.0 \pm 0.9 \\
(6.0-8.0)\end{array}$ & $\begin{array}{c}7.4 \pm 0.8 \\
(6.0-8.0)\end{array}$ & $\begin{array}{c}11.4 \pm 0.8 \\
(10.1-12.0)\end{array}$ & $\begin{array}{c}12.9 \pm 2.7 \\
(10.8-16.0)\end{array}$ \\
\hline Body diam.at lip region & $\begin{array}{c}6.8 \pm 1.3 \\
(5.0-8.0)\end{array}$ & $\begin{array}{c}8.5 \pm 1.4 \\
(6.8-10.0)\end{array}$ & $\begin{array}{c}9.2 \pm 1.8 \\
(7.9-12.0)\end{array}$ & $\begin{array}{c}10.7 \pm 1.5 \\
(8.1-12.0)\end{array}$ & $\begin{array}{c}12.7 \pm 1.5 \\
(12.0-14.0)\end{array}$ & $\begin{array}{c}12.7 \pm 1.2 \\
(12.0-14.0)\end{array}$ \\
\hline Body diam. at guiding ring & $\begin{array}{c}13.7 \pm 1.03 \\
(12.0-14.8)\end{array}$ & $\begin{array}{c}16.0 \pm 3.6 \\
(12.0-20.0)\end{array}$ & $\begin{array}{c}20.0 \pm 0.0 \\
(20.0-20.0)\end{array}$ & $\begin{array}{c}24.1 \pm 2.5 \\
(21.0-29.0)\end{array}$ & $\begin{array}{c}29.1 \pm 1.7 \\
(27.5-32.0)\end{array}$ & $\begin{array}{c}30.3 \pm 2.1 \\
(28.0-32.0)\end{array}$ \\
\hline $\begin{array}{l}\text { Body diam. at base of } \\
\text { oesophagus }\end{array}$ & $\begin{array}{c}22.9 \pm 0.7 \\
(22.0-24.0)\end{array}$ & $\begin{array}{c}34.5 \pm 4.4 \\
(32.0-40.0)\end{array}$ & $\begin{array}{c}41.5 \pm 2.8 \\
(39.2-46.0)\end{array}$ & $\begin{array}{c}49.0 \pm 5.4 \\
(40.0-60.0)\end{array}$ & $\begin{array}{c}54.8 \pm 4.8 \\
(44.0-60.0)\end{array}$ & $\begin{array}{c}56.0 \pm 0.0 \\
(56.0-56.0)\end{array}$ \\
\hline Body diam. at mid-body or vulva & $\begin{array}{c}22.8 \pm 1.6 \\
(20.0-24.0)\end{array}$ & $\begin{array}{c}35.9 \pm 4.5 \\
(32.0-40.0)\end{array}$ & $\begin{array}{c}48.0 \pm 4.1 \\
(44.0-55.6)\end{array}$ & $\begin{array}{c}56.2 \pm 5.8 \\
(46.0-68.4)\end{array}$ & $\begin{array}{c}66.4 \pm 7.5 \\
(54.0-80.2)\end{array}$ & $\begin{array}{c}62.7 \pm 1.2 \\
(62.0-64.0)\end{array}$ \\
\hline Body diam. at anus & $\begin{array}{c}15.3 \pm 1.9 \\
(12.0-17.0)\end{array}$ & $\begin{array}{c}28.1 \pm 3.8 \\
(24.4-33.0)\end{array}$ & $\begin{array}{c}37.5 \pm 1.5 \\
(36.0-40.0)\end{array}$ & $\begin{array}{c}44.3 \pm 3.3 \\
(40.8-48.0)\end{array}$ & $\begin{array}{c}49.3 \pm 3.6 \\
(42.0-52.8)\end{array}$ & $\begin{array}{c}50.7 \pm 1.2 \\
(50.0-52.0)\end{array}$ \\
\hline Body diam. et beginning of $\mathrm{J}$ & $\begin{array}{c}9.0 \pm 1.0 \\
(8.0-10.0)\end{array}$ & $\begin{array}{c}15.8 \pm 4.3 \\
(12.0-20.0)\end{array}$ & $\begin{array}{c}21.5 \pm 3.3 \\
(18.0-27.0)\end{array}$ & $\begin{array}{c}26.4 \pm 1.4 \\
(24.1-28.0)\end{array}$ & $\begin{array}{c}30.4 \pm 2.6 \\
(27.0-35.0)\end{array}$ & $\begin{array}{c}21.3 \pm 2.2 \\
(20.0-23.8)\end{array}$ \\
\hline Spicules & - & - & - & - & - & $\begin{array}{c}74.7 \pm 4.2 \\
(70.0-78.0)\end{array}$ \\
\hline
\end{tabular}




\section{Results and discussion}

Morphology (Fig. 1 - 2).

Morphometrics of females, males and four larval stages of L. profundorum from the locality Gajary is presented in Table 1. The measurements and morphology agree well with those of original desriptions of the species from England (Hooper, 1965) and with very detailed description from Switzerland (Lamberti et al., 2001). The most important characteristic for Slovak specimens are: Average length of females is $6.9 \mathrm{~mm}$, males $6.3 \mathrm{~mm}$, truncate lip region not set off, amphidial pouches pocket-like distinct bilobed, characteristic pouches are distinct already at the first stage juvenile ( Fig 1E - F). They are extended till about $60 \%$ of the distance between oral aperture to guide ring. Odontostyle of the length of about $101 \mu \mathrm{m}$ ( females) and $92 \mu \mathrm{m}$ (males), vulva slightly posterior to mid body, occupying about $65 \%$ of body diameter, gonads paired, opposed and reflexed, anterior branch of the length of about $650 \mu \mathrm{m}$, posterior of $550 \mu \mathrm{m}$. Tail roundly conoid, short, $\mathrm{c}^{\prime}$ about 0.9 . Male tail with prolongated hemi-elliptical terminus, length of spicules of about $75 \mu \mathrm{m}$, number of supplements $13-15$. The presence of three expressive caudal papillae at one male was observed (Fig. 2). Proportion of males to females was $1: 3$. The first larval stage is characteristic by a subdigitate tail, other three stages juvenile are with conoid rounded tail, shortening from second to fourth stage juvenile, corresponding with index $c^{\prime}=2.6$ at first to $c^{\prime}=1.0$ at forth stage juvenile.

At investigated sampling site the species $L$. profundorum was occurring in a mixture with second one longidorid species L. helveticus. The most important morphological

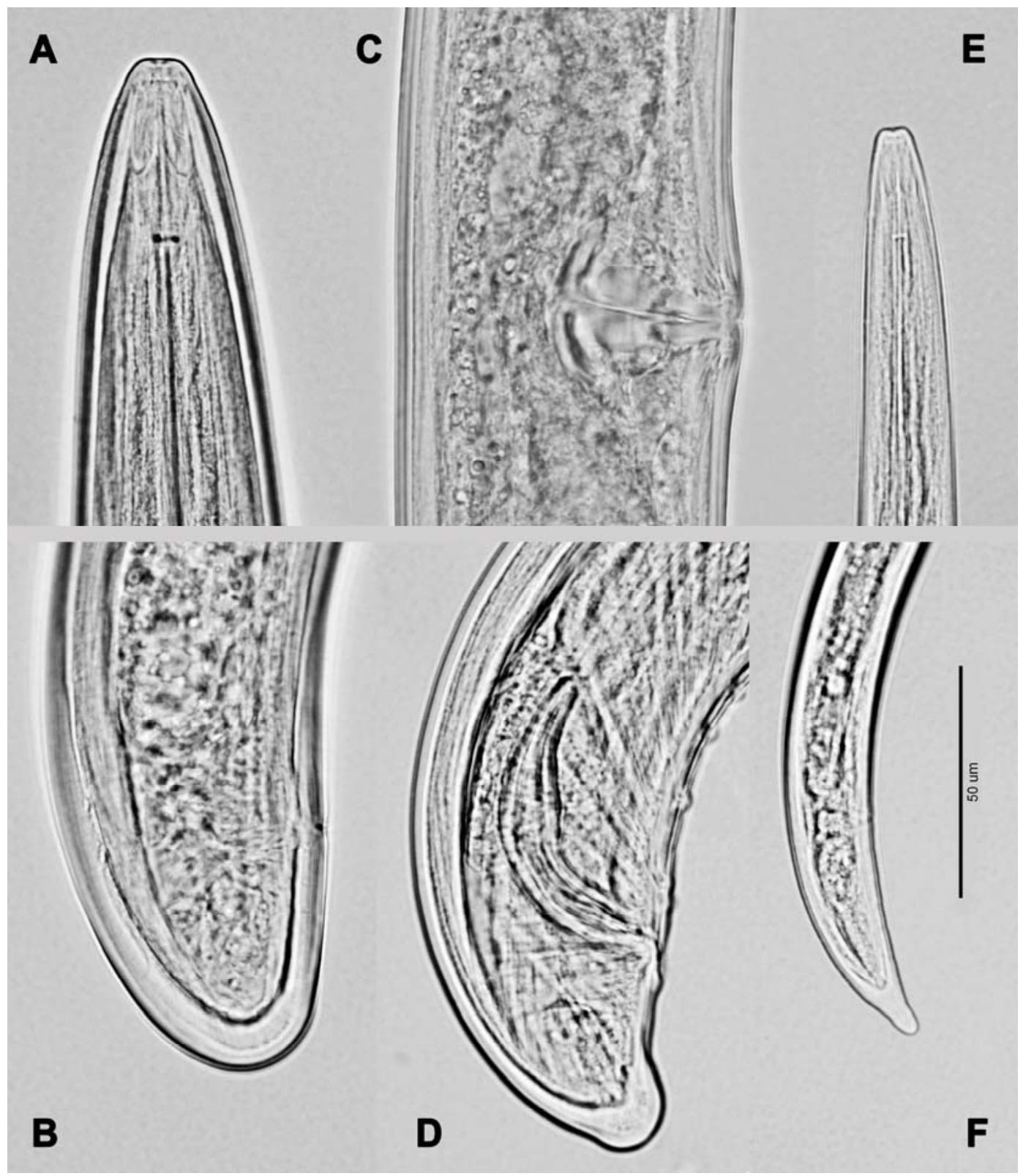

Fig. 1. Longidorus profundorum: A - female, anterior region; B - female, posterior region; C - female, vulva region; D - male, posterior region; 


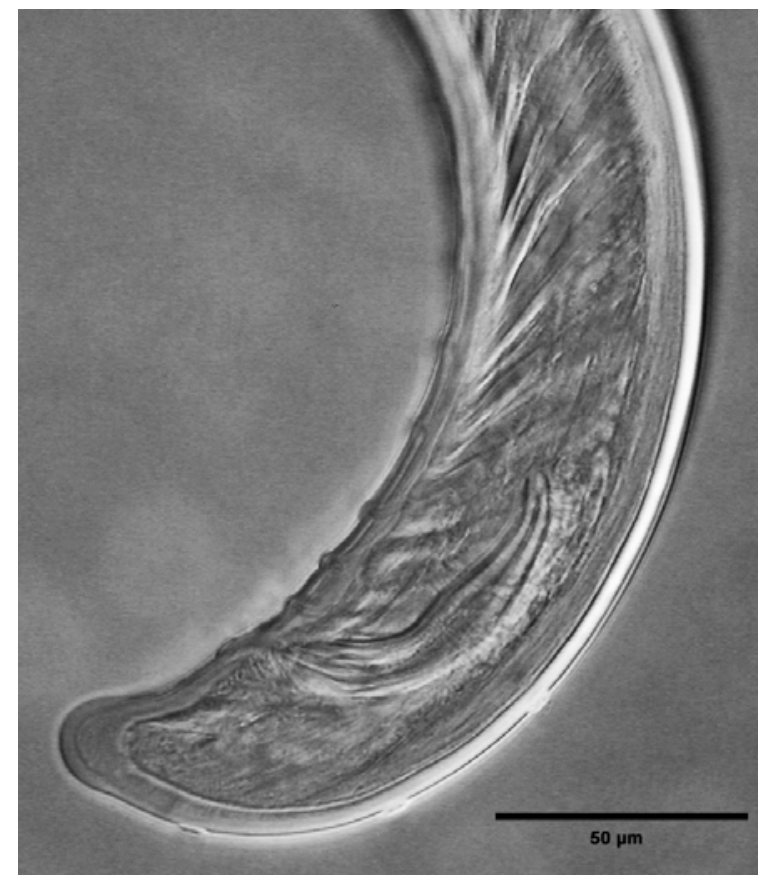

Fig. 2. Longidorus profundorum: Mail, posterior region with three distinct caudal papillae

differences in comparison with L. helveticus: At L. helveticus body is slightly longer, much robust, head more rounded, amphidial pouches not bilobed. Important difference is in the length of odontostyle, at L. helveticus it was $144 \mu \mathrm{m}$ and at females and $139 \mu \mathrm{m}$ at males vs. $101 \mu \mathrm{m}$ at females and $92 \mu \mathrm{m}$ at males at $L$. profundorum. Female tail shorter, blant rounded, at males tail not with distict prolongated hemi-elliptical terminus, much longer length of spicules $(102 \mu \mathrm{m} v s .75 \mu \mathrm{m})$. The tail of first stage juvenile digitate at both species, but at L. helveticus with much longer hyaline portion $(18.6 \mu \mathrm{m} v s .9 .5 \mu \mathrm{m})$.

\section{Molecular characteristic}

The D2/D3 expansion segments of 28S gene and 18S gene of ribosomal DNA were sequenced from two single individuals. Identical sequences were obtained for both individuals for each gene. The sequences were compared by Basic Local Alignment Search Tool (BLAST) in National Center for Biotechnology Information (NCBI) and the result showed $100 \%$ identity with $L$. profundorum accession number AF480073 (Rubtsova et al., 2001) for D2/D3. Though top fits of sequence of $18 \mathrm{~S}$ gene (accession number JQ359005) from the same DNA of single individual nematode were to Longidorus, but the sequences of this specimen is different from already deposited sequence of L. profundorum accession number EU503143 (Pedram et al., 2008). Sequence of D2/D3 expansion segments is not deposited on Genbank because it is $100 \%$ identical to accession number AF480073.

Notices to ecology

During a large nematological study of the occurrence of longidorid nematodes in various types of vegetation
(Lišková \& Brown, 2003), including investigation in floodplain forests (Lišková \& Sturhan, 2000) in Slovakia, the occurrence of $L$. profundorum was not recorded. Recently, the species was observed in additional soil samples from flooded forest along Moravia River, between Slovakia and Austria. After numerous informations throughout the Europe, it seems that the species is preferring cultivated soils with fruit orchards and vineyards, or fruit and grapevine nurseries (Hooper, 1965; Klingler et al.; 1983, Bleyer \& Rüdel, 1996; Hübschen et al., 2005; Romanenko, 1994), but the species was recorded also in arable soil with legumes and cereals (Andres \& Bello, 1984) and in rhizosphere of grasses and bushes (Hooper, 1965) and in soil of unspecified natural habitats (Brown \& Taylor, 1987). In agreement with Andres and Bello (1984) the species was also occurring in Slovakia in similar more heavy clayloamy soils. The area of floodplain forests along Moravia River, similar to other rivers, it is characteristic by variability of soil types (depended on origin of river sediments) from light sandy, very often gravelled soils to heavy clay soils. At the same locality Gajary during our previous study of longidorids in flooded forests in light sandy soils we recorded the species L. poessneckensis in mixture with Xiphinema diversicaudatum (Lišková \& Sturhan, 2000). Present observation of $L$. profundorum in floodplain forests indicates variability in occurrence of longidorids in this type of ecosystem.

\section{Acknowledgements}

The author is very thankful to Dr. Shesh Kumari for molecular analyses. The study was supported by VEGA Scientific Grant Agency, Grant No. 2/0136/10.

\section{References}

ANDres, M. F., BELlo, A. (1984): Soil influence and cultural methods about Longidorus profundorum phytoparasitic nematode of interest in cereal cropping areas of the central region (Spain). An. Edafol. Agrobiol. 43 (5 - 6): $727-734$

BLEYER, G., RÜDEL, M. (1996): Ist die Nematodenforschung von Rebschulböden erforderlich? Untersuchungsergebnisse aus Baden-Württemberg und Rheinland-Pfalz. Dtsch. Weinb. Jb., 47: 85 - 94

Brown, D. J. F., BoAG, B. (1988): An examination of methods used to extract virus-vector nematodes (Nematoda: Longidoridae and Trichodoridae) from soil samples. Nematol. medit., 16 (1): 93 - 99

Brown, D. J. F, TAYLOR, C. E. (1987): Comments on the occurrence and geograpgical distribution of longidorid nematodes in Europe and the mediterranean region. $\mathrm{Ne}$ matol. mediterr., 15 (2): 333 - 373

De Ley, P., Félix, M. A., Frisse, L. M., Nadler, S. A., SternberG, P. W. \& ThOMAs, W. K. (1999): Molecular and morphological characterisation of two reproductively isolated species with mirror-image anatomy (Nematoda: Cephalobidae), Nematology, 1: $591-612$ 
Holterman, M., Wurff, A. V. D., Elsen, S. V. D., Megen, H. V., Bongers, T., Holovachov, O., BAKKeR, J., HELDER, J. (2006): Phylum-wide analysis of SSU rDNA reveals deep phylogenetic relationships among nematodes and accelerated evolution toward crown clades. Mol. Biol. Evol., 23: 1792 - 1800. DOI: 10.1093/molbev/mls044 HoOPER, D. J. (1965): Longidorus profundorum n. sp. (Nematoda: Dorylaimidae). Nematologica, 11 (4): 489 - 495

HÜBSChEN, J., KlInG, L., IPACH, U., ZINKERNAGEL, V., Brown, D. J. F., NeILson, R. (2004): Development and validation of species-specific primers that provide a molecular diagnostic for virus-vector longidorid nematodes and related species in German viticulture. Eur. J. Pl. Path., 110 (9): 883 - 891. DOI: 10.1007/s10658-004-4841-x Klingler, J., GüntZel, O., KunZ, P. (1983): Xiphinema und Longidorus - Arten (Nematoda) im schweitzerischen Mittelland. Vjschr. Naturforsch. Gesell. Zürich, 128 (2): $89-114$

Lamberti, F., Kunz, P., Grunder, S., Molinari, S., De LuCA, F., Agostinelli, A., RAdicci, V. (2001): Molecular characterization of six Longidorus species from Switzerland with description of Longidorus helveticus sp.n. (Nematoda: Dorylaimida). Nematol. mediterr. 29 (2): 181 $-205$

LiŠKOVÁ, M., BROWN, D. J. F. (2003): Longidoridae (Nematoda: Dorylaimida) in the Slovak Republic. Helminthologia, 40 (3): $165-172$

LIŠKOVÁ, M., STURHAN, D. (2000): Occurrence and ecolo- gy of Longidoridae (Nematoda: Dorylaimida) in floodplain forests in the Slovak Republic. Helminthologia, 37 (2): 113 $-117$

Pedram, M., Niknam, G., Robbins, R. T., Ye, W., KAREGAR, A. (2008): Longidorus kheirii n. sp. (Nematoda: Longidoridae) from Iran. Syst. Parasitol. 71 (3): 199 - 211 PRIKHODKO, Y. N. (1988): Biological aspects for assesing, antinematode measures applied in nurseries and new orchards of apples under growing conditions in the middle Russia area. Autoref. Kand. Diss., Moscow, 24 pp.

ROMANENKO, N. D. (1994): Plant-parasitic nematodes of the family Lonfidoridae - vector of viruses, their association with nepoviruses and the study of the control methods in strawberry plantations and vineyards. Parasitologicalical Institute of Russian Academy of Sciences, Moscow, 84 pp.

Rubtsova, T. V., Subbotin, S. A., Brown, D. J. F. And MoENS, M. (2001): Description of Longidorus sturhani sp. nov. (Nematoda: Longidoridae) and molecular characterization of several Longidorid species from Western Europe. Russ. J. Nematol., 9 (2): 127 - 136

Stanton, J. M., McNicol, C. D., Steele, V. (1998): Nonmanual lysis of second-stage Meloidogyne juveniles for identification of pure and mixed samples based on the polymerase chain reaction. Australas. Plant Path., 27: 112 $-115$

TOPHAM, P. B., AlPhEY, T. J. W. (1985): Faunistic analysis of longidorid nematodes. Eur. J. Biogeogr. 12: 165 - 174 